\title{
The basaltic volcanic rocks in the Tuyon Basin, NW China: Petrogenesis and tectonic implications
}

\author{
Tao Liang*, Zhaohua Luo, Shan Ke, Li Li, Wentao Li and Huaming Zhan \\ School of Earth and Mineral Resources, China University of Geoscience, Beijing, 100083, CHINA \\ * To whom correspondence should be addressed. E-mail: tao_liang0212@hotmail.com
}

The Tuyon basin is located near the crossing of the Tien Shan orogenic belt, the Western Kunlun fold system and the TarimAlashan blocks. The crossing of two lithospheric scale fault, the Talas-Ferghana dextral strike-slip fault and the NE extended South Tien Shan strike-slip fault, isjust at the southern margin of theTuyon basin. Therefore, many geoscientists all over theworld have been attracted to petrogenesis of the Cenozoic basaltic volcanic rocksin the Tuyon basin and their tectonic implications. According to previous researches, the basalts emplaced within theTuyon basin are of two units, thelower basaltsand the upper basalts, aged 120 110Ma and 70.4 36.6 Ma respectively. All these basalts are classified as alkali series, enriched in potassium, and considered as a result of a small plume probably rooted at a shallow level in the asthenosphere.

Our new works on the igneous rocks in the Tuyon basin suggest that the so-called lower basalts are preserved as a series of conedikes, which areemplaced in Jurassic-Lower Cretaceous sedimentary rocks; the upper basalts are formed as a series of volcanic eruptions, including calderas, ring dikes, necks and volcanic cones. For example, there are three volcanic cones in the line between the Kuvt cone and Bilebluk cone. We have discovered basaltic intrusive units in Jurassic sandstone and conglomerate strata. The basaltic extrusive units have the same occurrence with the early Cretaceous sediments, but uncomfortably overlain by the Paleogene sedimentary rocks. Therefore, the Tuyon basin is a compound volcanic basin, including series of volcanic eruptions with lavas and subvolcanic rocks, rather than it has two-layer structure consisted of two igneous units. Our investigations indicatethat the basaltic rocks aremainly of dark gray, massivestructureand porphyritic texture. The basaltic extrusive rocks are developed as columnar joint structure, vesicular structure and amygdaloidal structure. Most of volcanic rocks within Tuyon basin contain phenocrysts such as olivine, clinopyroxene and plagioclase, and occasionally phlogopite, amphiboleand apatite. Olivine belongs to chrysolite circled by fine-grained aggregate of magnetite and talc. Most of olivine phenocrysts have been altered into iddingsite and talc. Theclinopyroxenemainly belongs to augite, which characterize hourglass structure and zoned texture. The plagioclase phenocrysts have more content of anorthite. They are mainly andesine and occasional labradorite, but rare in zoned texture. The matrix minerals are clinopyroxene, plagioclase, magnetite and volcanic glass, and mainly formed tholeiitic texture, occasionally intergranular textureand vitrophyric. Therefore, the Cenozoic volcanic rocksin theTuyon basin show characteristics of alkali series, and suggest that theregion may wasatextensional condition.

In the Arhesaiordy volcanic-sedimentary sequences there are five basaltic sills intruded into the Jurassic sedimentary deposits. Many megacrysts havebeen found in thelowest basaltic layer, such as augite, phlogopite, amphibole and anorthoclasite. From the same layer we have collected lots of the deep-seated xenoliths including peridotite, granulite, pyroxenite, gneiss and so on. In the other four layers, the number of megacrysts and deep-seated xenoliths has been decreased quickly. Therearealso lots of deep-seated xenoliths in the Tasgeler caldera. Therefore, basaltic magma has the characteristics of rapid ascent. Consequently, the basaltic volcanic rocks in the Tuyon basin are formed direct from primary magma, which is rare affected by fractional crystallization.

As mentioned above, basaltic volcanic rocks in theTuyon basin arenot likely to bethe products of two tectonic stages, and the previous $\mathrm{K}-\mathrm{Ar}$ and ${ }^{40} \mathrm{Ar} /{ }^{39} \mathrm{Ar}$ geochronology reports seem questionable. For the tectonic condition, the thrusts and nappe structures in the north margin of the Tarim basin indicate that thelocal lithosphere is in compressional condition. Therefore, it is difficult to explain the petrogenesis by mechanism of a small mantle plume or rifting. At the same time, the paleomagnetic evidences indicate that the Tuyon massif and Tarim block have united during Triassic and they drifted northward together, but Tuyon massif has rotated clockwise about $10^{\circ}$ relative to Tarim block during the Late Cretaceous. Therefore, we suggest that basaltic magma process should responseto therotation tectonic event and all of the rocks may represent a single igneous event. Theblock rotation is partial tectonic activity and induced by huge strike-slip faults during the process of the continental collision between Indiaand Asia. Theevidenceis that the mantle-derived igneous rocks are limited to the vicinity of the crossings of the hugestrike-slip faults. 